\title{
Myelin Antibodies Measurement
}

National Cancer Institute

\section{Source}

National Cancer Institute. Myelin Antibodies Measurement. NCI Thesaurus. Code C103418.

The determination of the amount of the myelin antibodies in a sample. 